\begin{tabular}{c} 
AFRICAN \\
EAST-ASIAN \\
AFFAIRS \\
\hline THE CHINAMONITOR
\end{tabular}

\title{
Regional inequality in distribution of the economic devel- opment results in China
}

\author{
By Ewa Cieślik* \\ Faculty of International Business and Economics, \\ Poznan University of Economics, Poland
}

\section{Introduction}

Despite the fact that China's economy on the whole has been developing at a fast pace for three decades this development and its positive results does not equally affect all regions of the country and social groups. The asymmetrical process of China's economic development constitutes one of the main unfavourable consequences of the reforms introduced after 1978. The economic changes resulted in the modification of resource allocation, the improvement of economic effectiveness and partial decentralisation. However, only selected provinces and social groups benefit from these changes.

The aim of this study is to present the current stratification of the distribution of income and development results among particular provinces and regions of People's Republic of China (PRC). An attempt is also made at pointing out the most highly developed regions of the country and such areas which lag far behind the provinces leading in the level of development. This paper adopts three taxonomic methods and statistical analysis of development indicators covering 31 of China's administrative regions: provinces, municipalities (Beijing, Tianjin, 
Shanghai, and Chongqing) and autonomous regions (Tibet, Xinjiang, Inner Mongolia, Ningxia, and Guangxi). This analysis based mostly on official data published by National Bureau of Statistics in China.

\section{The overall picture of social and regional disparities in China}

What testifies to the unequal distribution of wealth among the members of society is the recent appearance of the millionaire class in China. According to the last "World Wealth Report 2011" in China live 535,000 people with the financial assets worth at least 1 million USD. The growth of HNWIs (high net worth individuals) in 2010 amounted 12 percent and ranked Chinese millionaires fourth in the world (World Wealth Report 2011). By contrast to a number of Chinese HNWIs, nowadays, it is estimated almost 128 million people live below the international poverty line ( 9.5 percent of total population $)^{1}$. The nation has paid for the fast economic progress with high disproportions especially evident in the distribution of household income, which is testified to by the growing value of the Gini coefficient (graph 1). Before the reforms of 1978, China was one of the most egalitarian countries in the world. Officially, China's authorities have not published Gini coefficient since 2007, what may bear testimony that this indicator still growths. 


\begin{tabular}{|c|} 
AFRICAN \\
EAST-ASIAN \\
AFFAIRS \\
\hline THE CHINAMONITOR \\
\hline
\end{tabular}

\section{Graph 1. China's Gini coefficient for China in 1978-2007 (percent)}

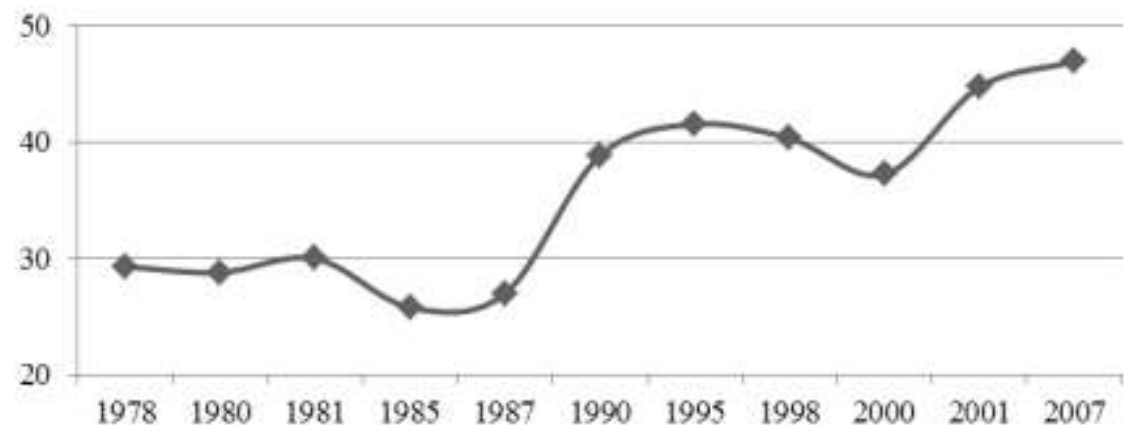

Source: Authorial study on the basis of: Human Development Reports from different years.

By introducing in 1978 the strategy called "Four Modernisations" the PRC's reformers concentrated on small Eastern provinces - a choice which was dictated by the latter's convenient location. These areas were supposed to conduct dynamic trade exchange and attract foreign investments. The government expenditures during the first years of transformation were directed mainly into the creation of provinces' infrastructure where special economic zones (Shantou, Shenzhen, and Zhuhai in Guangdong; Xiamen in Fujian and the entire island province of Hainan) were established. The singled out areas were initially

\footnotetext{
* The author is researcher at Poznan University of Economics, Poland, Faculty of International Business and Economics and cooperates with Nicolaus Copernicus University in Torun, Poland, Faculty of Political Sciences and International Studies
} 
supposed to incorporate themselves and subsequently the whole of China to make use of the positive consequences (Huang, Kuo, Kao, 2003; Khan, Riskin, 2001). The government expected a cylinder effect - the high dynamic of economic development might have pervaded the whole China's area. Unfortunately, the scale of this diffusion did not rise up to expectations. Actually, the country was divided into three areas: Eastern - full beneficiary of the effects of dynamic economic development, Central - laying claim to the beneficial consequences of the economic development, but still only participating in the actual development to a lesser degree, and Western - backward, peripheral and to a large extent excluded from China's development. This paper compares China's provinces in terms of macroeconomic indicators which consider internal development and foreign relations. What was also made evident was the social stratification relating to the place of residence ${ }^{2}$. The people of China are presently divided into those inhabiting rural areas and those who live in urbanized regions. This stratification is constituted by the hukou system (system of household registration). The former group makes much lesser use of the positive effects of development in contrast to the people living in the cities. However this paper excludes stratification problems to focus more precisely on the disproportions among China's provinces.

\section{GDP disproportions}

The provinces included in the Eastern areas of China are characterised by a high participation in the country's GDP and a high value of production in the industry and tertiary sectors which testifies to the advanced status of these economies. In 2006, Eastern provinces 


\section{AFRICAN \\ EAST-ASIAN \\ AFFAIRS \\ THE CHINA MONITOR}

generated 58.7 percent of China's total GDP in current prices while the Western areas generated 14.1 percent of GDP. The disproportions are deepening slightly, in 2010 Eastern provinces participation in China's GDP amounted 59.5 percent; in turn, Western territories generated 13.8 percent (graph 2, 3). The GDP generated by Guangdong was almost ninety-one times higher than the GDP of China's poorest province Tibet in 2010 (China Statistical Yearbook 2011) ${ }^{3}$. This enormous GDP gap between the most and the least developed regions increased over two last decades twenty-two times (National Bureau of Statistics in China).

Considering GDP composition, the most advanced structure characterized in 2010 Eastern regions, where share of tertiary sector in GDP accounting for 43.5 percent (more than country's average), industry and construction sector produced 49.6 percent and the agriculture generated only 6.9 percent. In Western provinces these indicators amounted to 37.3 percent, 49.5 percent, and 13.2 percent respectively and in Central - 35 percent, 52.4 percent and 12.6 percent respectively (National Bureau of Statistics in China).

An interesting case is Sichuan, which ranked among the top ten provinces in terms of regional GDP. In the presented rank this region generated larger GDP than some wealthy Eastern provinces (e.g. Shanghai, Fujian or Beijing). However, Sichuan's great part of its GDP is generated by extensive agriculture and this province is one of the poorest regions in terms of GDP per capita. In light of this, where should we look for the source of this high GDP level? The solution to this riddle lies in Chengdu - Sichuan's capital. In Chengdu, economic and technological development zones were established. This area has attracted a 
number of the most known transnational corporations, e.g. IBM, Microsoft, Symantec, Cisco, Intel, Siemens, Motorola, Nokia, Ericsson, Alcatel or Accenture. This high-tech park's share in province's GDP was significant. In 2010 only the high-tech products accounted for more than 21 percent of the province's GDP (HKDTC Research). Sichuan is also located among the top ten provinces of China in numbers of patents application accepted and granted (National Bureau of Statistics in China).

\section{Graph 2. China's GDP in current prices and its composition by regions in 2010 (billion $\mathrm{RMB}$ )}

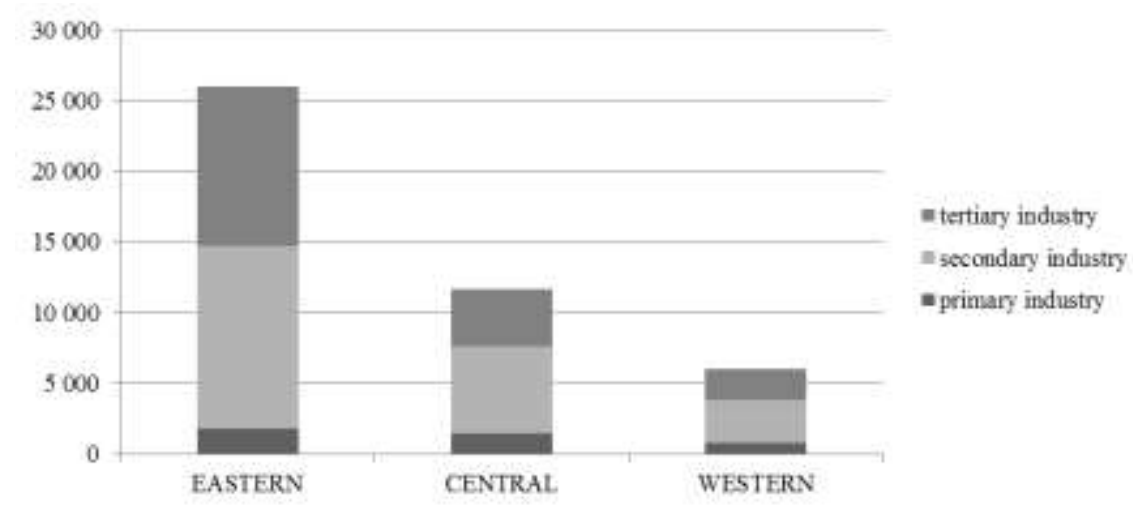

\section{Notes:}

- Eastern regions consist of: Beijing, Tianjin, Hebei, Liaoning, Shanghai, Zhejiang, Jiangsu, Fujian, Shandong, Guangdong, Guangxi, and Hainan.

- Central regions consist of: Shanxi, Inner Mongolia, Jilin, Heilongjiang, Anhui, Jiangxi, Henan, Hubei, and Hunan.

- Western regions consist of: Chongqing, Sichuan, Guizhou, Yunnan, Tibet, 


\section{AFRICAN \\ EAST-ASIAN \\ AFFAIRS \\ THE CHINA MONITOR}

Shaanxi, Gansu, Qinghai, Ningxia, and Xinjiang.

Source: Authorial study and estimation on the basis of: China Statistical Yearbook 2011, National Bureau of Statistics in China, China Statistics Press, Beijing 2011.

\section{Graph 3. China's GDP by provinces and sector in 2010 in current prices (billion RMB)}

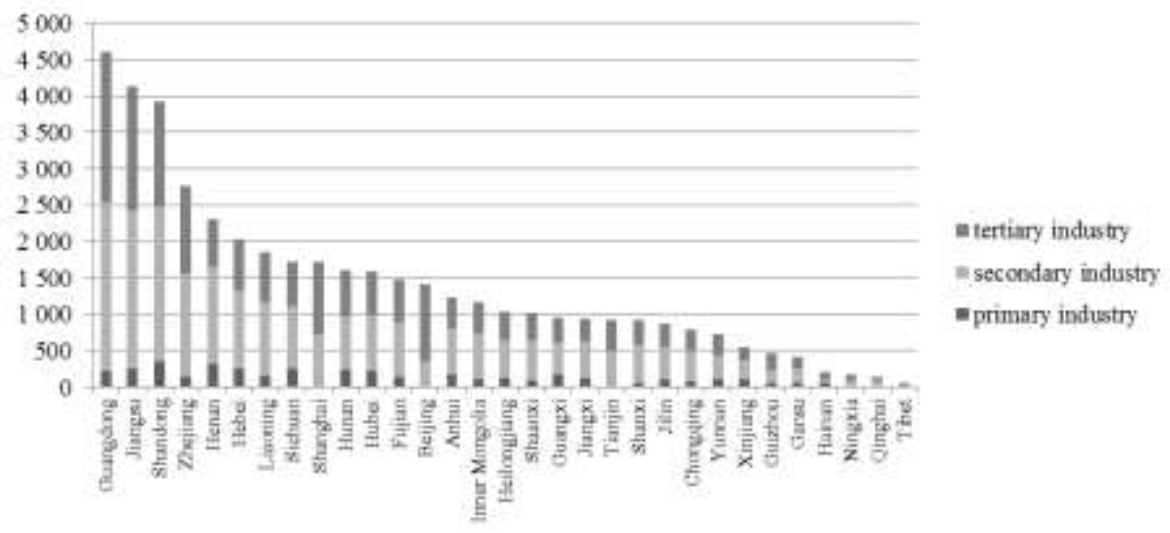

Source: Authorial study and estimation on the basis of: China Statistical Yearbook 2011, National Bureau of Statistics in China, China Statistics Press, Beijing 2011.

With respect to provinces, one observes significant diversification of fundamental economic development measures per capita. In 2006 the highest GDP per capita in current prices was generated by Eastern provinces - 23,858 RMB. In the Central regions' GDP per head amounted to around 13,231 RMB and the lowest value of GDP per capita was generated by Western provinces - 10,298 RMB. Until 2010, the disproportion 
in GDP per capita has not diminished noticeably - the indicator in the Eastern provinces amounted 46,741 RMB and in Western ones - 21,338 $\mathrm{RMB}$. Comparing the value of this indicator for each province to the average China's GDP per capita, only eleven provinces exceed country's average GDP per capita (five years ago there were twelve provinces). Between the province with the highest level of GDP per capita - Shanghai and the province that generated the lowest GDP per capita - Guizhou was almost six-times gap in 2010 (graph 4.).

\section{Graph 4. Diversification of the average annual income per capita by provinces in 2010 in current prices (thousand RMB)}

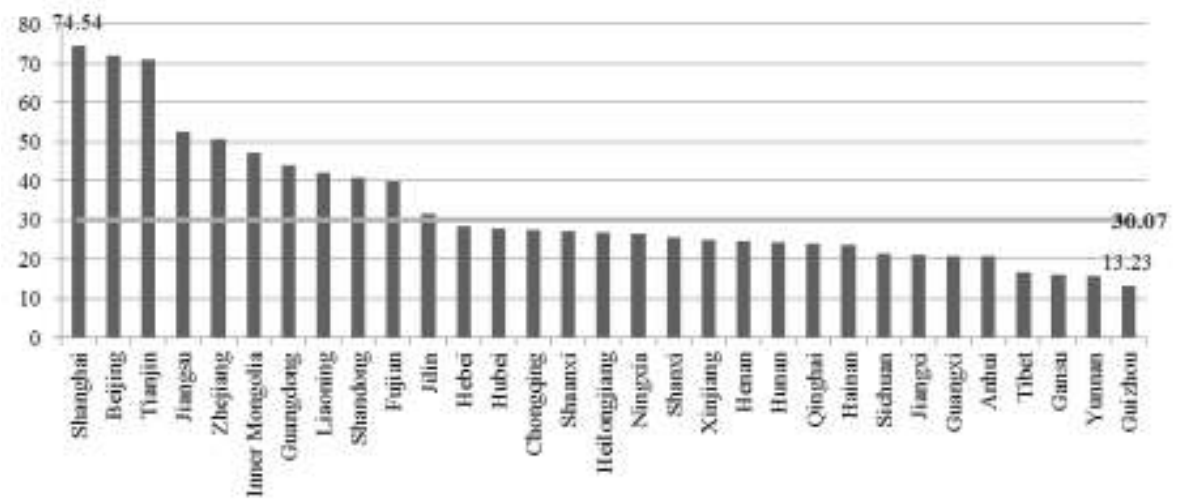

Source: Authorial study and estimation on the basis of China Statistical Yearbook 2011, National Bureau of Statistics in China, China Statistics Press, Beijing 2011.

\section{Disproportions in expenditure on consumption}




\begin{tabular}{l} 
AFRICAN \\
EAST-ASIAN \\
AFFAIRS \\
\hline THE CHINAMONITOR
\end{tabular}

Chinese society can be described as the ascetic in terms of consumption, which derives from its tradition and cultural factors. Chinese gather unprecedented savings (financing rapid capital accumulation) at consumption's expense. The savings rate in 2009 amounted to 48 percent, while the consumption rate reaches only 36 percent. These indicators are higher than Japanese national savings and investment rates in the peak of county's development patch (N'Diaye, 2010). What is worth noticing is that a tendency of consumption stratification is becoming evident as a result of the widening of the income gap. The disproportions in GDP are accompanied by the differentiation of the overall expenditure on consumption in particular provinces calculated with respect to one inhabitant. The highest overall consumption expenditure in 2010 was generated by the Eastern provinces (39.5 percent of all expenditures), especially Guangdong (graph 5). This is related to this region's high foreign trade activity and the inflow of the foreign direct investments. In addition, the provinces generating the highest GDP and GDP per capita are in the lead in relation to the consumption expenditures made. In all the provinces the urban household expenditures dominate. Consider government consumption: there were two provinces where this type of expenditures dominated over the rest. In Tibet and Xinjiang most of the expenditures in 2010 were carried out by the government (central and local), 59 percent and 45 percent respectively. It is the result of intensive government investment programmes, under the banner of the "Great Western Development" campaign - directed to the least developed regions of the country (especially Western provinces). The consumption expenditures, calculated with respect to one inhabitant of a particular province, show the evident domination of the expenses made by people living in Shanghai and Beijing (40,921 RMB and 40,303 RMB 
respectively). The expenditure gap between Shanghai and Guizhou (the last region in the rank below) was almost five (graph 6.). However, an improvement has been evident. In 1999 the gap between the region with the highest expenditure on consumption and the province where people spent the least on consumption goods was six times (National Bureau of Statistics in China).

\section{Graph 5. Overall consumption expenditure of rural and urban house- hold by province in current prices in 2010 (billion RMB)}

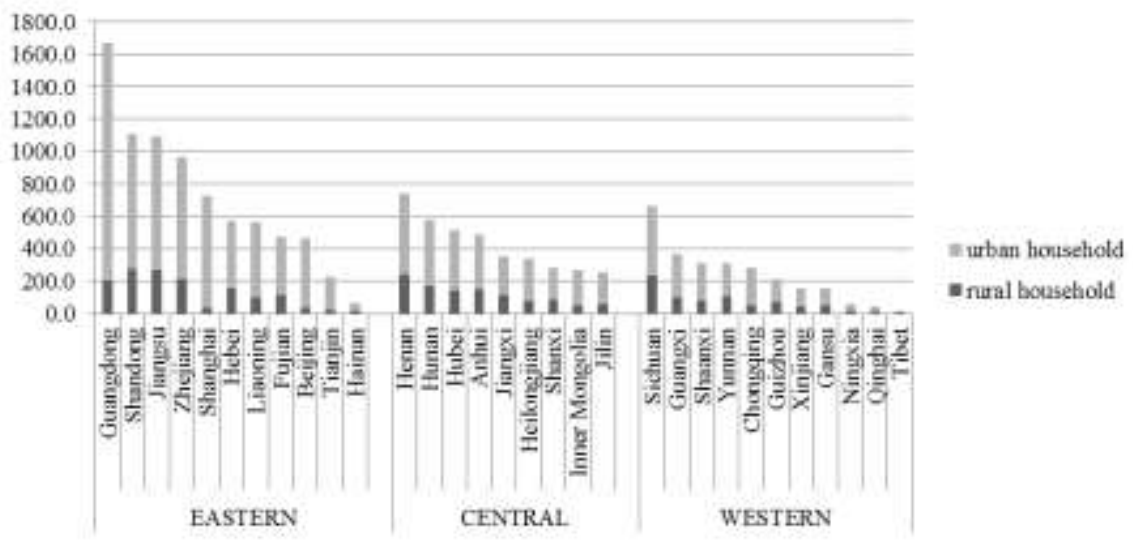

Source: Authorial study on the basis of China Statistical Yearbook 2011, National Bureau of Statistics in China, China Statistics Press, Beijing 2011. 
AFRICAN

EAST-ASIAN

AFFAIRS

THE CHINA MONTTOR

\section{Graph 6. Average annual consumption expenditure per capita by province in current prices in 2010 (thousand RMB)}

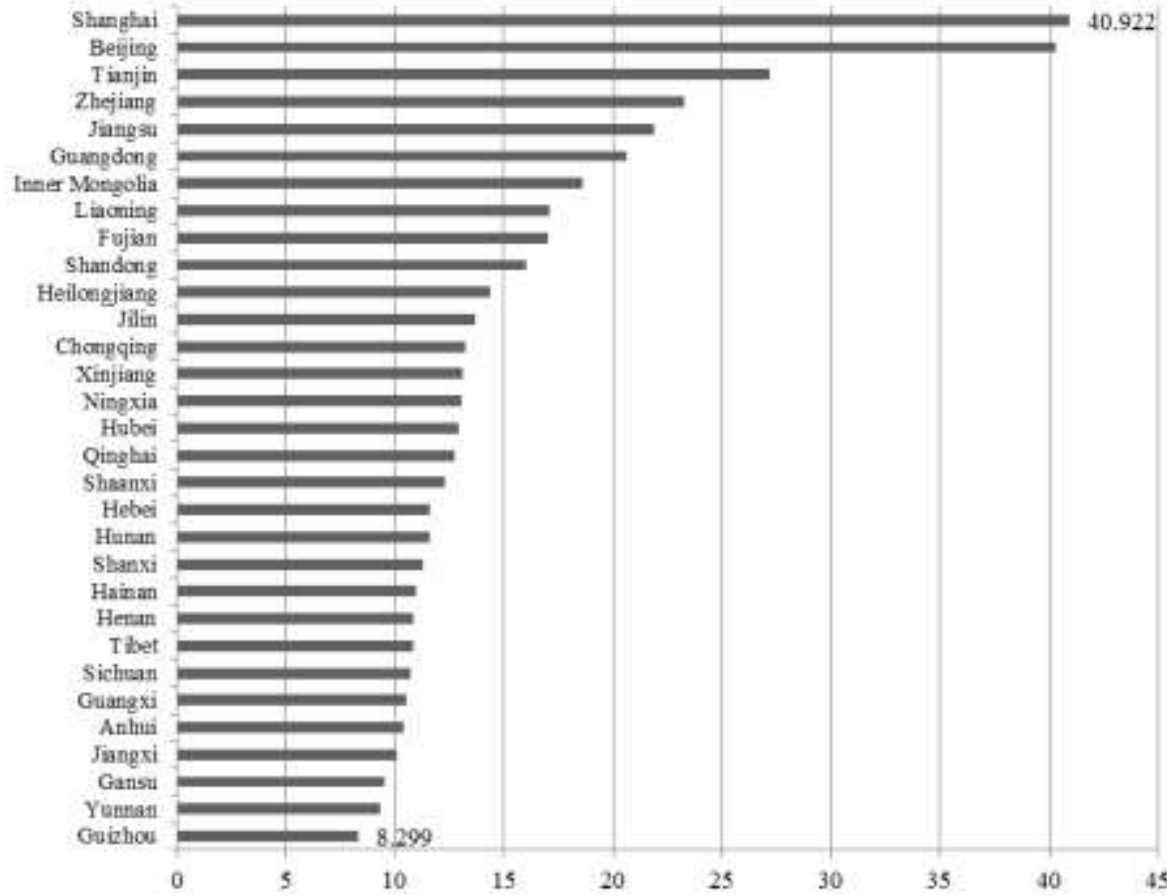

Source: Authorial study and estimation on the basis of Statistical Yearbook 2011, National Bureau of Statistics in China, China Statistics Press, Beijing 2011. 


\section{Disproportions in investment and $R \& D$ expenditure}

The disparate amount of GDP generated in particular provinces is accompanied by the appearance of the disproportions in the total investment in fixed assets. The fixed assets investment expenditures are close to the distribution of GDP among the provinces. The largest total investment in fixed assets were made in 2010 by the Eastern provinces (especially Shandong, Jiangsu, Henan, Liaoning, and Guangdong), but the rate of investment accounted for the largest share in Tibet, Anhui and Jiangxi (graph 7,8). The appearance of Sichuan in the top ten provinces in terms of largest investment spending is related with establishing special economic zones mentioned earlier, building appropriate infrastructure, and reconstruction process after earthquake in 2008. The high rates of investment in fixed assets in underdeveloped Western regions of China can be explained by the government's strategy of developing Western and Central provinces. These regions are beneficiaries of the central and local government spending programmes focused on development inequality reduction. The investments project in these regions are mostly implemented by state-owned enterprises, the private capital has not been employed notably. 


\section{Graph 7. Total investment in fixed assets by region in 2010 in current prices (billion RMB)}

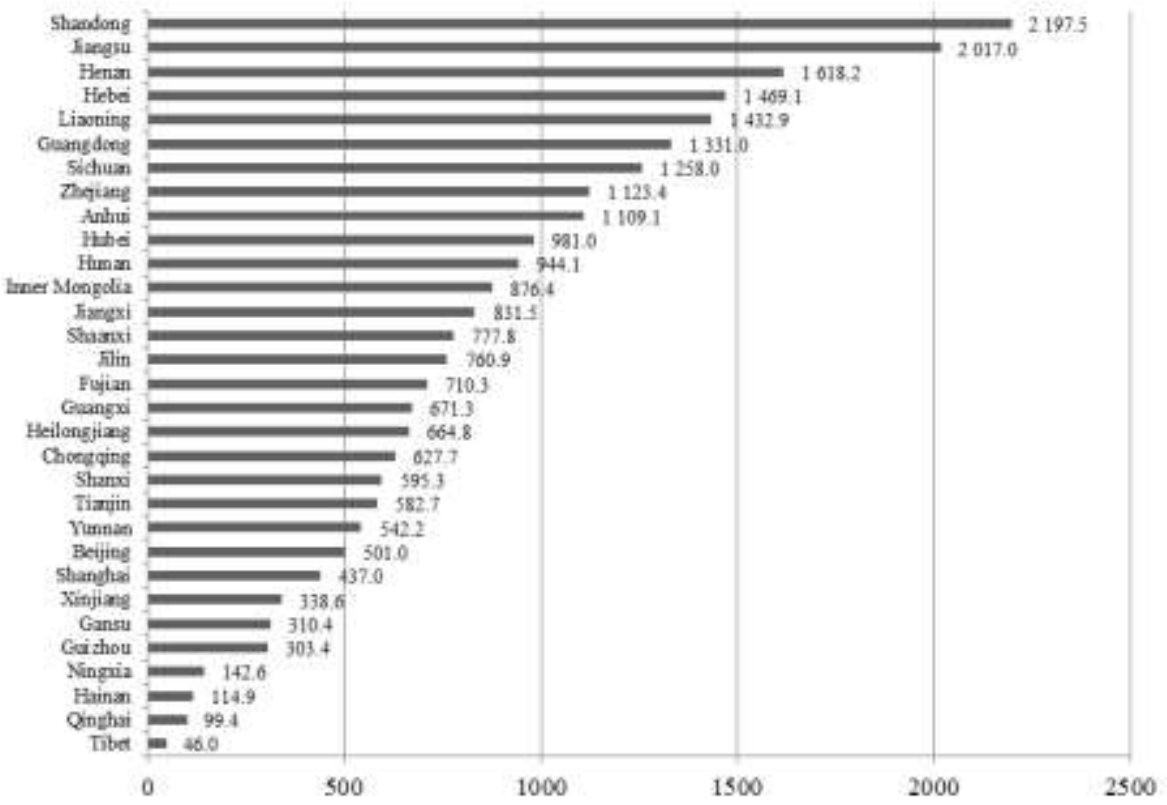

Source: Authorial study on the basis of China Statistical Yearbook 2011,

National Bureau of Statistics in China, China Statistics Press, Beijing 2011. 


\section{Graph 8. Total investment in fixed assets rate by region in $\mathbf{2 0 1 0}$ (percent of GDP)}

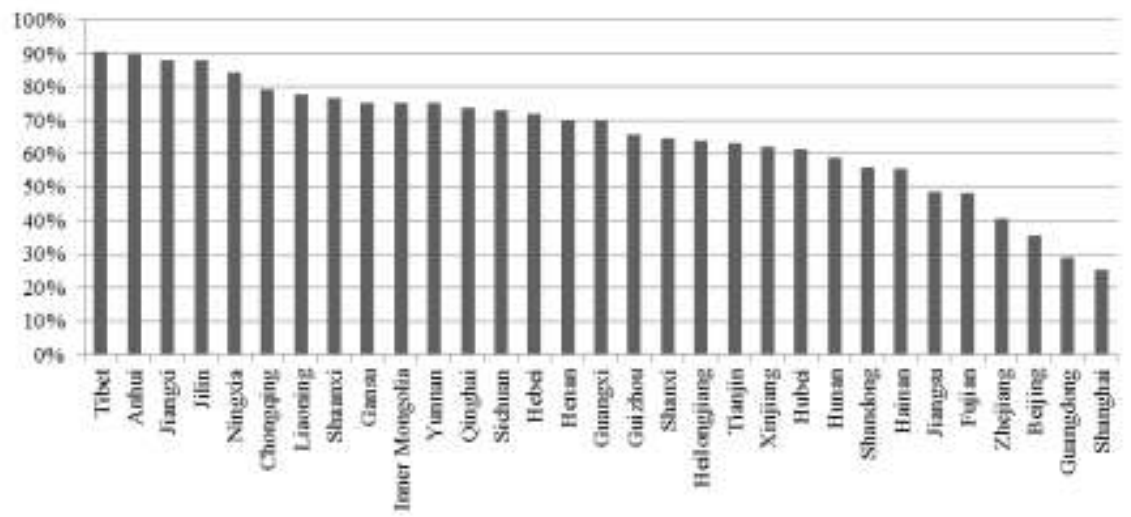

Source: Authorial study on the basis of China Statistical Yearbook 2011, National Bureau of Statistics in China, China Statistics Press, Beijing 2011.

The amount of regional GDP is followed by the resources dedicated to research and development (R\&D). China's share in world R\&D expenditures accounted 13.1 percent in 2011 (www.rdmag.com). China is the world's second in R\&D expenditure after the United States. In terms of R\&D spending share in GDP, China ranked below the world average (2 percent). In 2011, 1.5 percent of China's GDP was directed to R\&D sector. It is not a high participation rate in comparison to the U.S. or Japan, in which R\&D expenditure as percent of GDP amounted to 2.8 percent and 3.5 percent respectively. However, China's authorities plan to boost R\&D spending to 2.2 percent of GDP by 2015. There is a large gap in R\&D spending among Eastern provinces and the rest of the area. The largest number of funds was dedicated to this activity in 2011 in the Eastern 


\begin{tabular}{l} 
AFRICAN \\
EAST-ASIAN \\
AFFAIRS \\
\hline THE CHINAMONITOR \\
\hline
\end{tabular}

provinces - Jiangsu (12.2 percent of the national R\&D expenses), Guangdong (12 percent), Beijing (10.8 percent), Shandong (9.7 percent), Zhejiang and Shanghai (6.9 percent each). Provinces such as Tibet, Hainan or Qinghai almost do not make any expenses on research and development (National Bureau of Statistics in China; China Daily).

The high value of the $R \& D$ expenses in Eastern provinces is the result of two factors. First, the foreign capital's presence which is very lively as far as research and development activity is concerned. Second, such value can be attributed to the appearance and cooperation among science institutes, universities and business in high-tech zones. These determinants have accelerated China's economic development in Eastern regions for three decades. The R\&D expenses also influence other indices, e.g. the number of patent applications made, the high-tech product share in overall production, or the number of scientists and specialists employed. The above mentioned measure-points reach their highest values in the provinces with the highest overall GDP and the highest expenses on R\&D as well as in the ones most open to foreign contacts.

\section{Disproportions in labour productivity}

There is also the diversification between the provinces in the scope of labour productivity. The most productive workers at the end of 2010 were employed in the Eastern provinces: Shanghai, where average employee generated 185,635 RMB, Tianjin (177,126 RMB), and Beijing (107,111 $\mathrm{RMB})$. It is a result of accelerated development supported by foreign and domestic capital, and technology spill-overs that these regions have attracted for three decades. The country's average labour productivity amounted to 57,426 . Low worker efficiency of an average worker is characteristic for the poorest Western provinces in which the productivity was several times 
lower than the average employee from the Eastern provinces. For example, worker productivity was almost ten times higher between Shanghai and Guizhou (graph 9). Fortunately, we can observe the slow convergence among regional labour productivity. For instance, in 2006 the labour efficiency gap between the most and the least productive provinces differed by a ratio of twelve (National Bureau of Statistics in China). China ranked among countries achieving the highest growth of labour productivity. In 2000-2010 the dynamic of labour productivity amounted to around 14 percent (The Economist, 2011).

While the labour efficiency divergence has improved for last years, the remuneration gap is also shrinking if we consider the official data. Official average wage statistics represents the earnings of a specific group of employed people in China known as "staff and workers", including layers of public employees from upper-ranking cadres down to workers in state-owned enterprises and public utilities. They essentially represent top-level labour and excluded a number of migrant or rural employees. In result, the statistics are distorted. In 2010, the difference between Shanghai and Heilongjiang was a ratio gap a little over two. Only eight regions exceed China's average monthly wage (449.77 USD) (graph 10), which is much less than world's average wage that amounted 1.480 USD in 2010, according to International Labour Organization (ILO). However, the average real wage in China has risen over the last decade constantly. In 2000-2010 the growth of China's real wages was estimated to be around 16 percent (The Economist, 2011b).

Included among the provinces with above-average wages is Tibet. Though the average wages in this province are ones of the highest, it does not bear testimony to the high life quality of the province's society. Urban enterpris- 


\begin{tabular}{|} 
AFRICAN \\
EAST-ASIAN \\
AFFAIRS \\
\hline THE CHINA MONITOR \\
\hline
\end{tabular}

Issue 2

November 2012

es in Tibet usually hire employees from other regions. They are usually high-skilled employees and high wages compensate them the difficult work conditions (e.g. the Tibetan climate). Most of native Tibetans are excluded from vacancies in enterprises.

\section{Graph 9. Labor productivity by region in w 2010 in current prices (thousand RMB)}

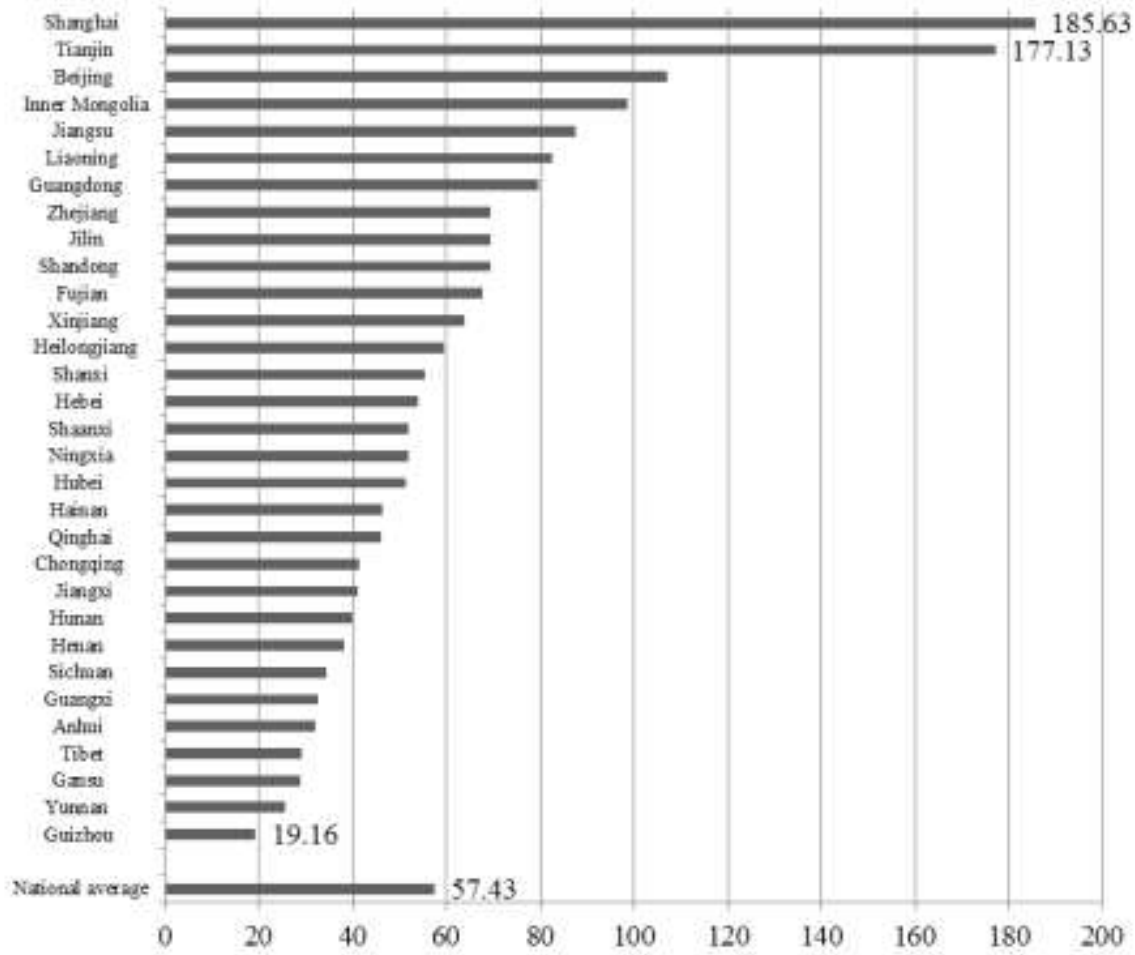

Source: Authorial study and estimation on the basis of China Statistical Yearbook 2011, National Bureau of Statistics in China, China Statistics Press, Beijing 2011. 


\section{Graph 10. Average monthly wage of employed person in urban units by region in 2010 in current prices (USD)}

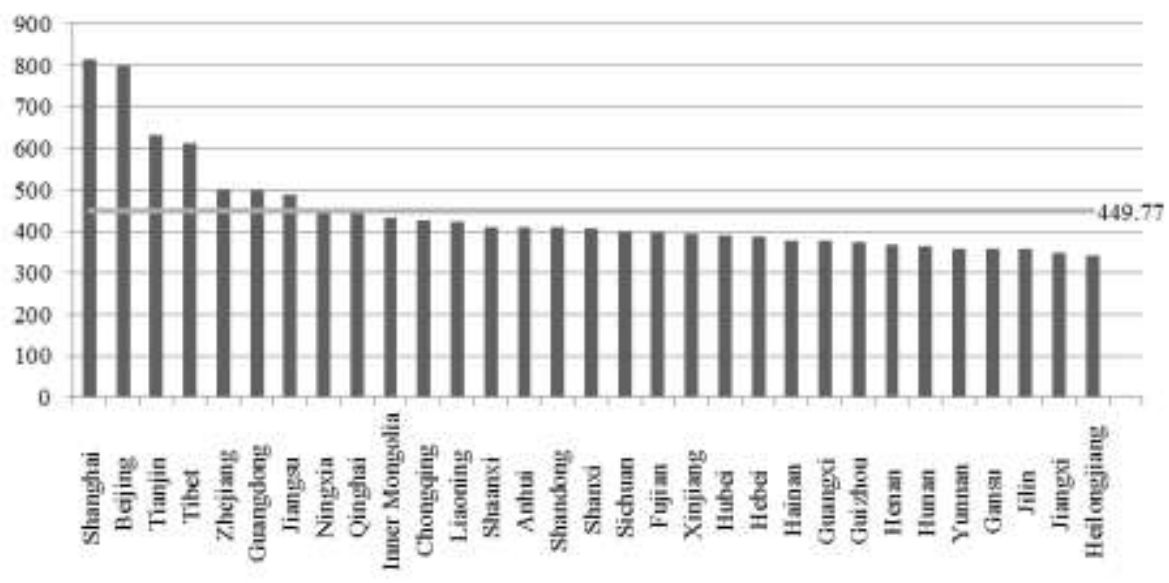

Source: Authorial study and estimation on the basis of China Statistical Yearbook 2011, National Bureau of Statistics in China, China Statistics Press, Beijing 2011.

\section{Disproportions in foreign trade and foreign direct investment}

During the introduction of the post-1978 transformations, the Chinese authorities were putting substantial emphasis on foreign exchange and the inflow of foreign direct investments. The singling out of privileged areas (special economic zones) at the beginning of the 1980s for trade exchange and the inflow of foreign direct investments resulted in the still visible division of the country into two zones based on their world economy connections: Eastern, which is developing predominantly owing to the globalization processes, and the rest of the country, which participates in the foreign trade on a minor scale and which virtually 


\section{AFRICAN \\ EAST-ASIAN \\ AFFAIRS \\ THE CHINA MONITOR}

does not benefit from foreign capital. At the end of 2010 the Eastern provinces completed around 90 percent of China's trade turnover. The four most active regions - Guangdong, Jiangsu, Shanghai, and Zhejiang - accounted for 65 percent of China's foreign trade (graph 11). From the beginning of the China's turn to a market economy, transformations in the Eastern provinces are also active in outward investments. The same provinces are also the most important beneficiaries of the foreign investments flowing into China. The biggest number of foreign companies is located in the Eastern regions of PRC. Hence, the fact of a much higher value of foreign direct investments made in the Eastern provinces than in the remaining regions is not surprising.

\section{Graph 11. Export and import value by region in 2010 in current prices (billion USD)}

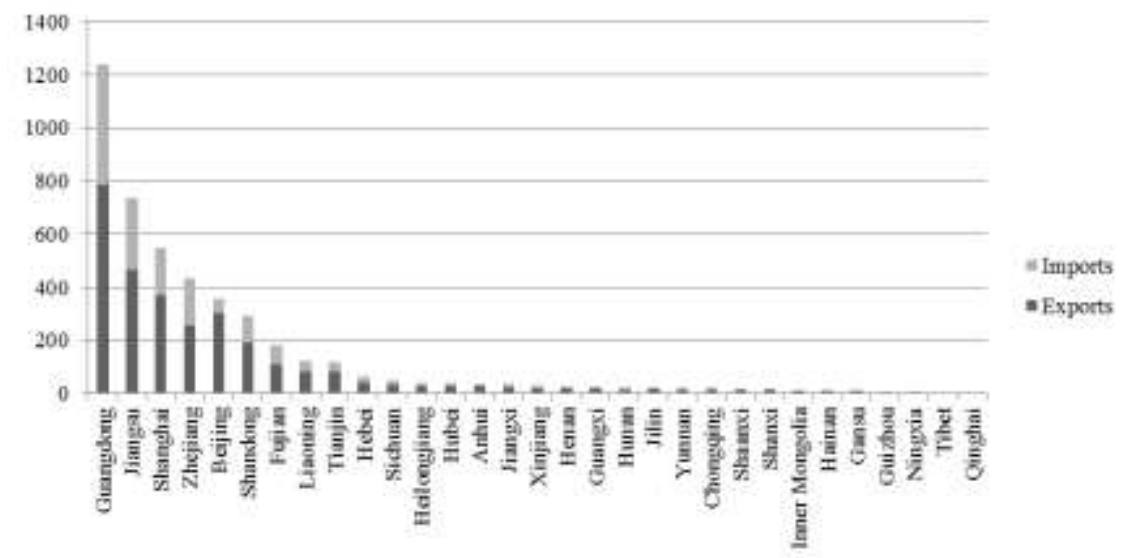

Source: Authorial study on the basis of China Statistical Yearbook 2011, National Bureau of Statistics in China, China Statistics Press, Beijing 2011. 


\section{Chinese province rankings}

Classifying Chinese provinces drew on the multi-dimensional index (taxonomy method). The result of this analysis shows that the higher regional GDP per capita the province generated, the higher positions in the rank it occupied. Employing three taxonomic methods of classification, the ranking of provinces has been formulated. This classification is based on 17 economic development indicators (the correlated ones have been excluded). The range of indicators applied to this method consists of:

1. Regional GDP to China's total GDP with respect to the surface of the region;

2. Regional GDP per capita;

3. Participation of primary industry production in total regional production;

4. Average work efficiency;

5. Total investment in fixed assets per capita;

6. Foreign trade per capita;

7. Foreign direct investment of foreign funded enterprises per capita;

8. Annual disposable income per capita;

9. Average earnings;

10. Consumption expenditure per capita; 


\section{AFRICAN \\ EAST-ASIAN \\ AFFAIRS \\ THE CHINA MONITOR}

11. Science and technology (S\&T) expenditure per capita;

12. Participation of S\&T expenditure in regional GDP;

13. Education expenditure per capita;

14. Number of higher education teachers per 10,000 inhabitants of province;

15. Number of students per 10,000 inhabitants of province;

16. Greenhouse gas emission per regional GDP unit;

17. Number of hospitals and health centers per 10,000 inhabitants of province.

During the standardization of chosen parameters and rejecting of correlated measures, the outcome confirms the earlier thesis that the Coastal (Eastern) provinces located on the highest positions in the rank. In turn, the lowest positions ranked were in the Western regions. The results of three applied methods were almost identical (table 1). The classification is similar to regions' rank in terms of average annual income per capita (graph 4). 


\section{Table 1. Chinese provinces rank in 2010}

\begin{tabular}{|c|c|c|c|c|c|}
\hline \multicolumn{2}{|c|}{$\begin{array}{c}\text { standardized by } \\
\text { average }\end{array}$} & \multicolumn{2}{|c|}{$\begin{array}{c}\text { standardized by range } \\
{[0 ; 1]}\end{array}$} & \multicolumn{2}{|c|}{$\begin{array}{c}\text { classical } \\
\text { standardization }\end{array}$} \\
\hline rank & & rank & & rank & \\
\hline 1 & Shanghai & 1 & Shanghai & 1 & Shanghai \\
\hline 2 & Beijing & 2 & Beijing & 2 & Beijing \\
\hline 3 & Tianjin & 3 & Tianjin & 3 & Tianjin \\
\hline 4 & Zhejiang & 4 & Zhejiang & 4 & Zhejiang \\
\hline 5 & Jiangsu & 5 & Jiangsu & 5 & Jiangsu \\
\hline 6 & Liaoning & 6 & Guangdong & 6 & Liaoning \\
\hline 7 & Guangdong & 7 & Liaoning & 7 & Guangdong \\
\hline 8 & Hainan & 8 & Inner Mongolia & 8 & Inner Mongolia \\
\hline 9 & Ningxia & 9 & Fujian & 9 & Jilin \\
\hline 10 & Inner Mongolia & 10 & Jilin & 10 & Fujian \\
\hline 11 & Fujian & 11 & Shandong & 11 & Shandong \\
\hline 12 & Jilin & 12 & Hainan & 12 & Shaanxi \\
\hline 13 & Qinghai & 13 & Shaanxi & 13 & Hainan \\
\hline 14 & Shandong & 14 & Ningxia & 14 & Ningxia \\
\hline 15 & Shanxi & 15 & Heilongjiang & 15 & Heilongjiang \\
\hline 16 & Shaanxi & 16 & Hubei & 16 & Hubei \\
\hline 17 & Heilongjiang & 17 & Chongqing & 17 & Chongqing \\
\hline 18 & Xinjiang & 18 & Qinghai & 18 & Qinghai \\
\hline 19 & Hebei & 19 & Xinjiang & 19 & Xinjiang \\
\hline 20 & Chongqing & 20 & Hunan & 20 & Hunan \\
\hline 21 & Hubei & 21 & Jiangxi & 21 & Shanxi \\
\hline 22 & Jiangxi & 22 & Shanxi & 22 & Jiangxi \\
\hline 23 & Hunan & 23 & Gansu & 23 & Gansu \\
\hline
\end{tabular}




\section{AFRICAN \\ EAST-ASIAN \\ AFFAIRS \\ THE CHINA MONTTOR}

Issue 2

\begin{tabular}{|l|c|c|c|c|c|}
\hline 24 & Gansu & 24 & Sichuan & 24 & Sichuan \\
\hline 25 & Sichuan & 25 & Henan & 25 & Henan \\
\hline 26 & Henan & 26 & Hebei & 26 & Hebei \\
\hline 27 & Anhui & 27 & Tibet & 27 & Anhui \\
\hline 28 & Guangxi & 28 & Anhui & 28 & Yunnan \\
\hline 29 & Yunnan & 29 & Yunnan & 29 & Guangxi \\
\hline 30 & Guizhou & 30 & Guangxi & 30 & Tibet \\
\hline 31 & Tibet & 31 & Guizhou & 31 & Guizhou \\
\hline
\end{tabular}

Notes:

- Standardized by average: ${ }^{x_{i}{ }^{\prime}=\frac{x_{i}}{\bar{x}}}$, where $x_{i}{ }^{\prime}$ - standardized value of " $i$ " element's attribute $X$; $x_{i}$-value of " $i$ " element's attribute $X$ before standardization process.

- Standardized by range $[0 ; 1]: x_{i}^{\prime}=\frac{x_{i}-x_{\min }}{x_{\max }-x_{\min }}$, where $x_{i}{ }^{\prime}-$ standardized value of " $i$ " element's attribute $X ; x_{i}-$ value of " $i$ " element's attribute $X$ before standardization process; $x_{\max }$ - maximum value of attribute $X ; x_{\text {min }}$ - minimum value of attribute $X$.

- Classical standardization: $x_{i}^{\prime}=\frac{x_{i}-\bar{x}}{s_{X}}$, where $x_{i}{ }^{\prime}$ - standardized value of " $i$ " element's attribute $X ; x_{i}-$ value of " $i$ " element's attribute $X$ before standardization process; $s_{x}-$ standard deviation. 


\section{Conclusions}

By developing dynamically, China has not avoided a number of negative consequences. The negative aspects of the vehement socio-economic changes in the Middle Kingdom do not exhaust the long list of unfavourable results of China's transformations. The choice of discrepancies in the distribution of China's rapid development effects was made subjectively following the belief that the negative phenomena which were pointed out might most severely hinder further development of the country. If one wants to eliminate the negative phenomena related to the lack of an egalitarian distribution of the results of PRC's economic development, then the problems mentioned should be taken into account in a comprehensive manner. This is because there exists a feedback between the negative consequences of China's development. The programme of the development of Western regions, introduced by the government in 1999, is not resulting in any satisfactory benefits. The underdevelopment of infrastructure, insufficient human capital, the problems in the flow of information, corruption, domination of the state sector and modest share in taking part in the opening-to-the-world strategy constitute some of the main problems of China's interior, especially the Western provinces (Lai, 2002). 


\section{AFRICAN \\ EAST-ASIAN \\ AFFAIRS}

\section{End Notes}

${ }^{1}$ It is worth notice that in 2011 China raised its poverty line to 1 USD per person per day (6.3 RMB per day). Earlier the poverty line adopted in Middle Kingdom was one of the lowest lines in the developing world. (The Economist, http://www.economist.com/blogs/freeexchange/2011/12/chinaspoverty-line).

${ }^{2}$ Before the reform in 1978 there were not so significant disparities. (Woo, 2007)

3 Guangdong Province shared 10.5 percent of total China's GDP, while estimation of Tibet's participation in GDP amounted 0.13 percent. (National Bureau of Statistics in China)

\section{References}

Hong Kong Trade Development Council (HKDTC) Research. Online: http:// research.hktdc.com/. Accessed 20 November 2012

Huang J., Kuo C., Kao A., 2001, The Inequality of Regional Economic Development in China between 1991 and 2001, "Journal of Chinese Economic and Business Studies", No. 3, p. 274.

International Labor Organization. 2008. World of Work Report 2008. Online: http://www.ilo.org/global/about-the-ilo/newsroom/news/WCMS 099406/lang-en/index.htm. Accessed: 20 November 2012.

Khan A.R., Riskin C., Inequality and Poverty in China in the Age of Globalization, Oxford University Press, p. 6.

Lai H.H., China's Western Development Program: Its Rationale, Implementation, and Prospects, 2002, "Modern China”, No. 4, p. 459. 
N'Diaye P., 2010, Transforming China: Insights from the Japanese Experience of the 1980s, "IMF Working Paper", No. 10/284, p. 10.

National Bureau of Statistics in China. 2011. China Statistical Yearbook 2011. China Statistics Press, Beijing.

National Bureau of Statistics in China. 2012. Online: http://www.stats.gov.cn/ english/. Accessed: 20 November 2012.

R\&D Magazine. 2012. "2012 Global R \& D Funding Forecast: R \& D Spending Growth Continues While Globalization Accelerates". Online: http:// www.rdmag.com/articles/2011/12/2012-global-r-d-funding-forecast-r-dspending-growth-continues-while-globalization-accelerates. Accessed: 20 November 2012.

The Economist. 2011. “Asian Labour Markets,” 27 August. Online: http:// www.economist.com/node/21526944. Accessed: 20 November 2012.

The Economist. 2011b. "China's poverty line: Life at the bottom of the middle kingdom,” 2 December. Online: http://www.economist.com/blogs/ freexchange/2011/12/chinas-poverty-line. Accessed: 20 November 2012 United Nations Development Project. 2011. Human Development Report. Online: http://hdr.undp.org/en/. Accessed: 20 November 2012.

Woo, W.T., 2007, The Challenges of Governance Structure, Trade Disputes and Natural Environment to China's Growth, Brookings Institution, Washington, D.C., p. 6. 